\title{
MALAYSIAN TERRORIST ORGANIZATIONS AND POTENTIAL INVOLVEMENT IN CRIMINAL ACTIVITIES
}

\author{
Mohd Mizan Mohammad Aslam*
}

\begin{abstract}
Homegrown terrorist organizations such as Kumpulan Militant Malaysia (KMM), Jemaah Islamiyyah (JI), Darul Islam Sabah (DIS), Al Qaeda and Islamic State (IS) or DAESH have created their own "domestic" criminal capabilities. The series of bombings and terrorist attacks which the terrorists have been known to carry out in this region cannot be done without a sturdy source of funding. Either small or big scale terror activities depends on funding, because terrorist operators and suicide bombers also need money for a living. Proactive vigilance and law enforcement activities aimed at stopping funding for terrorist organizations have halted their movements. As a result, they have lately been forming partnership with organized and underground crime groups in order to continue to survive. This study has identified the activities of at least four main terror-crime groups operating in Malaysia known as: human trafficking, piracy, kidnaping for ransom (KFR), and smuggling. Drawing on these accounts, it is discussed in this article that the level of a terrorist group's organizational capability is the most vital factor of the crimes they were engaged in. Significant data from the series of interview and literature review were used to produce output which would be able to help the authorities in Malaysia to have a wider understanding of the crime-terror nexus in Malaysia.
\end{abstract}

Keywords: Terrorism, KMM, JI, DIS, Al-Qaeda, IS, , Jihad, Syahid, Special Branch (SB), Islam, Caliph, Interpol

\section{Introduction}

The objective of this article is to explain the sources of funding for Malaysia's terrorist groups. All the funding has been accessed by militant groups. Up to date, Malaysia recorded 20 militant groups which have been operating nationwide since they first emerged in $1967 .{ }^{1}$ Each of these groups have their unique ways of finding money for terrorism related activities. The easiest way to understand this is to categorize their activities into three phases. First is right after independence until the millennium, the second phase is the period of wider funding and networking for Al-Qaeda and the last one is the ISIS smart-solo funding. ${ }^{2}$

During the era of Malaysia's post-independence from the $60 \mathrm{~s}$ to the $90 \mathrm{~s}$, terrorist organizations' sources of income were mainly from followers' personal donations. Considering the fact that they are hampered with limitations in terms of communication and finance, there wasn't much source of income for them. At that time, most people depended on traditional-economic based sources of income such as farming and fishing activities. At this stage, militant groups operated in their locality, hardly spread-out due to communication constraint. ${ }^{3}$ That is why the first militant group, Tentera Sabilullah only gained support in Bukit Mertajam and Sungai Petani, Kedah. The funding for buying machetes, knives, cross bows and many more traditional arms came from the followers' contributions. The same method of funding was adopted by Kumpulan Crypto, Golongan Rohaniah, KARIM, Kumpulan Nasir Ismail, KMK, Ibrahim Libya, KPIP, Jundullah, Al-Arqam and Maunah. ${ }^{4}$

However, the second phase of militants' operation in Malaysia had a different method of approach. This was in the millennium era between the years 2000 and 2013, which was highlighted with significant influence by Al-Qaeda. Kumpulan Militan Malaysia (KMM) and Jemaah Islamiyyah (JI)

\footnotetext{
* Mohd Mizan Aslam, Associate Professor, Centre for Technology Communication and Human Development (iKOM), Universiti Malaysia Perlis (UniMAP), Arau, Perlis, Malaysia. Email: m.mizan@unimap.edu.my/mohdmizan@gmail.com.

${ }^{1}$ R. Hashim (2007), Interview, 30 3 th December 2007 at Bukit Aman Police Head Quarters, Kuala Lumpur, Malaysia.

${ }^{2}$ Rohan Gunaratna (2018), “Counterterrorism: ASEAN Militaries' Growing Role - Analysis," RSIS Commentaries, retrieved $8^{\text {th }}$ June 2018, https://www.rsis.edu.sg/wp-content/uploads/2018/03/CO18042.pdf.

3 Mohd Mizan Aslam (2020), “Pemahaman Agama Ketika Wabak," Malaysiakini, retrieved 11 ${ }^{\text {th }}$ April 2020, https://www.malaysiakini.com/columns/520063.

${ }^{4}$ Rohan Gunaratna and Mohamed Ali (2014), Terrorist Rehabilitation: A New Frontier In Counter-terrorism, London: Imperial College Press.
} 
had direct access to funding from Al-Qaeda. Most of their followers work odd jobs to fund their lives and operations. With the influence of globalization, the world has become small and borderless. The effect of Al-Qaeda operatives such as Khalid Sheikh Muhammad (K.S.M.), Hambali and Nasir Abbas made the movement of money easy. Hence, a traditional based method which largely relies on trust was used for transferring money. It was also known as the hawala system and was widely used among operatives. This is a rather unique traditional system originated from Pakistan. It does not involve direct physical or online transfer, thus able to avoid detection. The perpetuators of the Bali bombing, Kuningan and J.W.Marriott attacks used money obtained from Al-Qaeda and the operation was secretly carried out by K.S.M and Hambali. Botched bank robberies in Petaling Jaya and Selangor also signaled the new method of sourcing for money to carry out their activities. When a bank was robbed in Medan during the year 2003, around USD20,000 realized from the operation was used for the 2003 Marriott bombing. ${ }^{5}$

Disputes between Osama Laden and Abu Bakar al-Baghdadi regarding the subject of attacks and method of killing of non-believers resulted in the establishment of ISIS in 2013. They started with a small fraction of the group who disagreed with the Al-Qaeda approach, creating Jabhat Al-Nusra in Syria which ended-up to be known as ISIL. Money laundering was widely used throughout that time. ISIL smartly funded their activities through legal business in various sectors such as tourism, international business and foreign exchange. The Royal Malaysian Police (RMP) initiated special units to oversee this kind of funding and they are specialized in Anti Money Laundering Act (AMLA). Darul Islam Sabah (DIS) and ISIS Malaysia also made use of the booming period in the global aviation industry for the laundering of money from person to person. It can be seen through the series of arrests done by RMP in terrorism related activities that included money laundering undertakings.

\section{Overview on ISIS Funding}

In order to understand the larger connection between crime and terror, it is necessary to know the current situation in countries ruled by terrorists, namely Iraq and Syria. Currently, ISIS has been declared as the most fortunate terrorist group. Matthew Lewitt in his evidence to the US House Committee on Financial Services stated that ISIS collected USD 3 million a day and USD 2.9 billion annually from various crime-terror activities. ${ }^{6}$ Given the fact that its total assets were up to USD 2 trillion just in a month after controlling Iraq and part of Syria, makes it the world's wealthiest terrorist group. ${ }^{7}$ With this amount of capital, ISIS draws more income than many small countries like Ethiopia, Uganda, Kongo, Tajikstan and many more. This statement was supported by Duhaime ${ }^{8}$ saying that by September 2014, just a year after ISIS's invasion in Iraq and Syria, their revenues of at least USD 2 billion from external and internal sources. Moreover, ISIS also publicly declared a USD 2 billion budget for 2015, indicating that they have a stern and sturdy income that can make them compete like normal sovereign states.

The question is how ISIS has become so expansive and wields the ability to control such a large amount of money. The answer lies in the fact that ISIS not only smartly chooses the area of operation, but they also manipulate unprecedented arrays of funding opportunities including oil reserves, bank robberies, looting of precious values of ancient artifacts, and kidnapping for ransom (KFR). Piracy also takes place by ISIS affiliated groups in the sea line area such as Gulf of Aden, Malacca and Sulu Straits. Compared to Al-Qaeda, ISIS is much more fortunate in their geographical area of control. AlQaeda operated in Afghanistan which is known as one of the poorest countries in the world. However, Afghanistan became the biggest opium producer just within a year after being taken over by Al-Qaeda. Even so, it is still not comparable to what was gathered by ISIS in just a month after their invasion of large territories in Iraq.

\footnotetext{
5 Mathias Hariyadi (2012), “Islamist Terrorist Suspected in Yogyakarta Robbery,” Asianews, retrieved $1^{\text {st }}$ March 2019, http://www.asianews.it/news-en/Islamic-terrorists-suspected-in-Yogyakarta-bank-robbery-25303.html.

${ }^{6}$ M. Levitt (2014), "Terrorist financing and Islamic State - Testimony submitted to the House of Committee on Financial Services," Washington Institute, retrieved $16^{\text {th }}$ November 2015, http://www.washingtoninstitute.org/policyanalysis/view/terrorist-financing-and-theislamic-state.

${ }^{7}$ Nicholas Ryder (2013), "Out with the old and...in with the old? A critical review of the financial war on terrorism on the Islamic state of Iraq and Levant," Studies in Conflict \& Terrorism, Vol. 41, No. 2, pp. 79-95.

8 C. Duhaime (2015), "Terrorist financing and the Islamic State," Duhaime Advisory, retrieved 17 ${ }^{\text {th }}$ November 2015, http://www.duhaimelaw.com/wp-content/uploads/2015/04/White-Paper-Terrorist-Financing-Methods1.pdf.
} 
One of the first funding sources of ISIS is the oil reserves known as the 'black oil market,' This includes selling to domestic users, to the Syrian army, as well as exporting to the United States and other countries. Reports by Hawramy, Mohammed and Harding ${ }^{9}$ stated that a sophisticated oil smuggling empire with other illegal exports was made to Jordan, Iran and Turkey. ${ }^{10}$ ISIS reportedly managed dozens of oil rigs and refineries within a month of their invasion particularly in Kirkuk and Mosul. The black oil empire was happy to have a deal with ISIS because of discounted prices and safety assurances. In one of the reports, it was mentioned that ISIS sold crude oil around USD10 to USD35 per barrel ${ }^{11}$ which is too far behind the real market price of between USD60 to USD90 per barrel. One of the biggest questions here is why is there no strike on ISIS controlled oil infrastructure during this period? Does it mean that most of the super powers are also gaining good profit from this illegal industry?

Secondly, ISIS secured their funding from KFR activities. This method is considered one of the most effective ways in securing funding. People from Oil Companies, tourists, journalists and humanitarian missions are easy targets of ISIS. Each of them was paid between USD10 million to USD30 million. ISIS also understood that most of the people who go to this region were covered by insurance with large amounts of coverage. Developed and rich countries like Japan, Italy, France, Germany, Spain and United Kingdom reportedly have paid big amounts of money in securing their citizens. At least USD10 million monthly was earned by ISIS from KFR activities in Iraq and Syria, as well as from their affiliated groups that operated in Philippines, Nigeria, Sudan and Egypt.

Some reports also mentioned about donations from individuals as well as private entities worldwide. These sympathizers used the same method as Al-Qaeda and channeled their funds through NonGovernmental Organizations (NGO) and humanitarian missions. Countries like Kuwait, Saudi and Qatar were cited as the biggest contributors of ISIS. ${ }^{12}$ However, portions from private funding represented a very small percentage compared to other sources. Levitt mentioned in his testimony submitted to the House of Committee on Financial Services, not more than USD40 million were scored by ISIS from various donors from Qatar, Saudi and Kuwait. ${ }^{13}$ The amount might be more because some of them had transferred the funds using the hawala style of transaction.

Furthermore, it is worthwhile to note that a significant amount of funding was gained from selling historic artefacts. Iraq has most of the world's precious treasures comes from Mesopotamia, Sumeria and Babylon. All of these sites were guarded by the Iraqi government officials as national treasure, however for ISIS it is considered as mungkar or un-Islamic, as the artefacts were derived from the jahiliyyah (before Islam) period. These can be sold as claimed by Abu Turki, the grand mufti of ISIS. ${ }^{14}$ The Wall Street Journal estimated that not less than USD100 million, in terms of funding, comes from the sales of artefacts. Middle men from European countries such as Germany, United Kingdom and Switzerland pay more than USD4 million in each transaction for dozens of artifacts. Levitt also stated in his report that one single lion statue was sold for more than USD50 million in New York back in 2007. ${ }^{15}$

Another source of income for ISIS comes from taxes. Every single person in their Kingdom has to pay jizyah or levy per head. In the early years of Islam, jizyah was imposed on non-Muslims only. However, ISIS has made some alterations on the concept of jizyah, in which every single person who lives in the caliphate has to pay jizyah as a symbol of sovereignty and having the rights protection. ${ }^{16}$ Another form of tax imposed by ISIS can be considered as extortion whereby every oil company that operates in their territory are required to pay legal tax. A significant amount of money obtained from

\footnotetext{
${ }^{9}$ F. Hawramy, S. Mohammed and L. Harding (2014), "Inside Islamic State's oil empire: how captured oilfields fuel Isis insurgency," The Guardian, retrieved $19^{\text {th }}$ November 2019, http://www.theguardian.com/world/2014/nov/19/-spislamic-state-oil-empire-iraq-isis.

${ }^{10}$ Ryder (2013), "Out with the old and...in with the old?" p. 80.

11 S. Osborne (2015), “ISIS earns \$50million month from oil sales," Independent, retrieved 24 ${ }^{\text {th }}$ October 2020, www.independent.co.uk/news/world/middle-east/isis-earns-50m-a-month-from-oil-sales-a6707146.html.

12 Vision of Humanity (2017), Global Terrorism Index, retrieved 12 th February 2019, http://visionofhumanity.org/app/uploads/2017/11/Global-Terrorism-Index-2017.pdf.

${ }^{13}$ Levitt (2014), "Terrorist financing and Islamic State."

${ }^{14}$ Mohd Mizan Aslam, Iffah Bazilah Othman and Nur Aqilah Khadijah Rosli (2016), "De-radicalization programs in South-East Asia: A comparative study of rehabilitation programs in Malaysia, Thailand, Indonesia and Singapore," Journal of Education and Social Sciences, Vol. 4, p. 157.

${ }^{15}$ Levitt (2014), "Terrorist financing and Islamic State."

${ }^{16}$ Levitt (2014), "Terrorist financing and Islamic State."; Mohd Mizan, Iffah and Nur Aqilah, "De-radicalization programs in South-East Asia,"p. 155.
} 
extortion was derived from Iraqi and Syrian oil resources. Laub and Masters said not less than USD8 million a month was netted by ISIS from extortion activities. ${ }^{17}$

ISIS was also involved in robbery, making it as one of the sources of income especially at the early stages of the Iraq and Syria invasion. In June 2014, ISIS raided Iraq's Central Bank in Mosul and scored as much as USD400 million and gold bullions. ${ }^{18}$ A significant amount of money also looted from banks in Iraq and Syria comprised up to USD1 billion by the end of 2014. ${ }^{19}$ This was considered the easiest way of securing funds as banks were known to be a place to keep money and gold. With a large amount of money in the hands of ISIS, that is how they can sustain for at least a year till their systems come in place especially after organizing a black market for oil and antiquities.

The sources of funding for these militant groups vary from period to period; namely the period immediately after the independence to the end of the last millennium, the post millennium period which involved the wider funding and networking by Al Qaeda, and lastly the period of immediate past which saw the introduction of smart solo funding by the ISIS. This is the smart transformation of the method of terrorism funding implemented by terrorist groups globally, using local and international wider networking.

ISIS is also known as the best equipped, the wealthiest and the most organized terrorist group to have emerged so far. ISIS has great ideas in securing funds to sustain their activities in the 8 years of Iraq and Syria invasion. Lessons learned from Al-Qaeda's failure in Afghanistan and Iraq has earned ISIS better reputation and has made ISIS become more well equipped in organizing their own kingdom. More or less, Abu Bakar al-Baghdadi, Ayman al-Zawahiri, Al-Zarqawi and Abu Fathima Junaishi are considered cleverer and have complete ideas in running a nation. Three main components which are considered necessary for running a nation, namely the administrative, legislative and judiciary, were embedded in the ISIS caliphate system. Yet, the most important part is to sustain their movement, and the way to do it is through securing funds which is what ISIS has done in their 8 years of Iraq and Syria invasion.

With such larger resources in Iraq and Syria, it is a good opportunity for ISIS to extend their operation worldwide. ISIS established their networking in war-torn areas such as Somalia, Yemen, Afghanistan and Nigeria. Simultaneously, ISIS also makes allies with local terrorist groups in Southeast Asia, South Asia and Middle East including Malaysia, the Philippines and Indonesia. Most of the local terrorist groups have made pledges of allegiance to the late Abu Bakar Al-Baghdadi and Ayman AlZawahiri. In return, the groups have been recognized as ISIS wider-arms and are subject to be funded. Stringent laws and establishments of anti-terrorism units all around the world have made ISIS and his allies to find vivid solutions, which is the use of bit-coins or crypto money. Significant amounts of crypto money have been channeled to the Abu Sayyaf Group and Jammah Ansharut Tauhid. ${ }^{20}$

\section{Malaysian Militants Group}

A major factor for the emergence of the fanatical ideology was Islamic revivalism. Islam remained the principal factor in dominating socio-politics in Malaysia decades ago. Malay Muslims believe, Islamic revivalism was a sense of going back to the basic tenets of Islamic teaching. It is important to purify oneself from maksiat (sin) and discard hedonistic and materialistic values brought by westerners. Furthermore, Islam also recognized syumul or the perfect way of life. 'Islam is a Way of Life', a set of universal, timeless, complete and fully detailed moral and wise values for the benefit of mankind. It is part of a voluntary charter or mutual contract between the Creator and His creation.

In addition, the creed that Islam is a syumul religion in every aspect of a Muslim's life including politics and governance has become the prominent theme of Islamic revivalism in Malaysia and world-wide. Islam is widely known as a religion that does not admit any separation between politics and religion. However, separation was implemented during colonization and also in the post-

\footnotetext{
${ }^{17}$ Z. Laub and J. Masters (2014), "ISIL in Iraq and Syria," Council on Foreign Relations, retrieved 22 $2^{\text {nd }}$ September 2014, http://www.cfr.org/iraq/islamic-state-iraq-syria/p14811.

${ }^{18}$ Laub and Masters (2014), "ISIL in Iraq and Syria."; Ryder (2013), "Out with the old and...in with the old?" p. 84.

${ }^{19}$ Laub and Masters (2014), "ISIL in Iraq and Syria.”; Ryder (2013), "Out with the old and...in with the old?" p. 84.

${ }^{20} \mathrm{~V}$. Arianti and Kenneth Yeo Yaoren (2017), "How Terrorists Use Crypto Currency in Southeast Asia," The Diplomat, retrieved $1^{\text {st }}$ July 2020, https://thediplomat.com/2020/06/how-terrorists-use-cryptocurrency-in-southeast-asia/.
} 
independence era in many countries including Malaysia. ${ }^{21}$ The grievances of political leaders during post-independence and the struggle to establish a purifying Islamic political system have been among major factors in employing a radical Islamic ideology. There are twenty 'Islamic militant' groups in Malaysia for the period since 1967 until 2019.

The first religious-based militant group existed in Malaysia was Tentera Sabilullah or a 'Holy War Army,' This group established in 1967 in relation to ethnic-clash incident in January 21, 1965. Haji Abdul Talib bin Haji Ahmad @ Haji Abdul Mutalib Naim from Kelang, Selangor established a group called Golongan Rohaniah in 1971. Four years later The Koperasi Angkatan Revolusi Islam Malaysia (Malaysian Islamic Revolutionary Front-KARIM). Ali bin Abdul Rani established KARIM in 1974 with the main objective to build Islamic Republic in Malaysia. The Kumpulan Cypto formed by Mokhtar bin Hassan in 1977 in Penang. Mokhtar strategically planned for new government called 'Theocratic Government' by jihad. Theocratic order is also known as 'The Government of Jesus.' In 1980, Mohd Nasir Ismail established a militant group in Kuala Lumpur. Nasir claimed he is the Mahdi or an awaited saviour for mankind. Nasir urged his followers to establish a new Islamic government by terrorist means.

Second wave of militancy in Malaysia had a big influence from Afghan-Russia war between 19791989. The Ustaz Ibrahim Libya established Kumpulan Revolusi Islam Ibrahim Libya (Ibrahim Libya Islamic Revolution Group) in 1985 in Baling, Kedah. However, this group ended with fourteen of his followers died during the fighting with Malaysia Royal Police. Later, Ustaz Abdul Latiff bin Mohammad formed a Kumpulan Jundullah in Kelantan. Latiff urged all of his followers to go for military training to prerpare themselves for Islamic government based in Malaysia. The first Malaysian mujahidin, Cikgu Non or Zainon Ismail established Kumpulan Mujahidin Kedah (KMK) with the main objective is to establish Islamic government with the help of Partai Islam Semalaysia or PAS members. This establishment followed by for mujahidin based in Perak state. With the help of PAS Youth leader, Sidek bin Mohd Noor formed Kumpulan Perjuangan Islam Perak (KPIP). This group secretly involved in a series of attack to gambling, brothel and any vices activities especially in the of Perak. However, the best part of this wave is the emergence of business cum extremists group called Al-Arqam. The peak of conflict between Arqam and government came after declaration of 313 military armed of Al-Arqam called Tentera Badar who tried to topple down the legitamate democratic government of Malaysia. Al-Maunah is nother militant group existed in Malaysia, this group was came to picture after Mohd Amin and his followers commit a treason and plotting to overthrow the government in order to be an Islamic state. They were found guilty of waging a war against the King. Al-Maunah known for their audacious military weapons robbery case at Military Campi in Grik, Perak.

Third wave of militancy in Malaysia marked with linkage with Al-Qaeda and ISIS. This is where many latest militant groups made their pledge of allegiance towards the establishment of Islamic Caliphate. Moreover, this group also participated in series of political and religious conflict in the region. The third wave of militancy started with Kumpulan Militan Malaysia in 1991. Cikgu Zainon establish KMM by gathering all of his networks under the alumni of Pakistan and India. KMM involved in a series of small-scale attacks as well as bank robbery for funding their activities. At the same time, Jemaah Islamiyyah also been established by exiled Indonesia extremists, Abu Bakar Ba'asyir and Hambali aka Reduan Isamuddin. JI known for their involvement and being mastermind in a series of bombings and attacks in Indonesia and the Phillipnes. Darul Islam Sabah (DIS) was established after crackdown of KMM and JI movement in peninsular of Malaysia. Some of JI and KMM members who were at run, went to the of Sabah and establish DIS secretly. DIS also a safe haeven for regional terrorists and a transit point for those who are ready to participate in Mandanao conflict. Islamic State (IS) and also known as DAESH establish in 2013 in Syria. However, their movement getting great support from Malaysian who were indoctrinated by online platforms. IS Malaysia also evolved in many splinters movement such as 'Black Crow,' Daulah Islam Malizia (DIM), Kumpulan Fisabilillah, Revolusi Islam and many more.

\footnotetext{
${ }^{21}$ Kamarulnizam Abdullah (1999), "National Security and Malay Unity: The Issue of Radical Religious Elements in Malaysia," Contemporary Southeast Asia, Vol. 21, No. 2, pp. 261-262.
} 


\section{The Links between Crime and Terror in Malaysia}

Post 911 terrorist attacks marked a new paradigm in militant movements around the world. Surveillance and intelligence efforts done by every single nation comes to the peak in halting terrorism activities. Continuous pressure has made terror-crime nexus emerging as an evolution in terrorism related activities. This linkage provides a new source of funding for terror activities. Furthermore, it also creates more complicated problems. In Malaysia, IS and DIS clearly make this nexus in securing funding due to what has happened since the millennium.

Organized crime and terrorism has been in place since long time ago. History recorded a close link between the two especially at the end of Cold War which led to a proliferation of terrorists turning to criminal activities to keep the organizations alive. This scenario happened as the state sponsored terrorism ceased due to geopolitics and globalization factors. Terror-crime nexus provided mutual benefits even though each of them have different agendas.

The commonality in violence between these two groups can be seen in a few criteria. First, the use of violence and killing activities such as driving vehicles into pedestrians, stabbing, bombing, shooting and any cruel methods. Second, targeting mass innocent civilians en masse because of lack in selfprotection. Thirdly is to draw attention and to give significant influence to any entity including the government and the whole world. ${ }^{22}$ Both terror and crime shared these common criteria in their operations irrespective of the size or distance of the set-ups. However, some scholars including Tamara Makarenko differentiated the objectives of these two movements. Tamara stated that terrorists engaged with criminals for the purpose of funding, while criminals engaged in terrorism to influence policy making towards their activities. ${ }^{23}$

\section{Human Trafficking}

Thousands of immigrants from Central Asia and Middle East are believed to have fled their countries for Australia, transiting in Southeast Asia. In August 2001, a vessel loaded with 430 immigrants was intercepted by Australian coastguards in the international sea between Indonesia and Australia. Human trafficking can be defined as "the recruitment, transportation, transfer, harboring or receipt of persons, by means of the threat or use of force or other forms of coercion, of abduction, of fraud, of deception, of the abuse of power or of a position of vulnerability or of the giving or receiving of payments or benefits to achieve the consent of a person having control over another person, for the purpose of exploitation. ${ }^{24}$

Many pushing and pulling factors contributed to the problem in relation to illegal immigrants trying to sneak in to more developed countries like Malaysia and Australia. Poverty, globalization and conflict are considered among the real causes of human trafficking in the region. Sex industry and rapid development in countries like China, Thailand, Singapore and Indonesia also contribute to human trafficking. Individuals who want to leave war and conflict in their countries have been exploited as well. Thailand and Malaysia have been recognized as a safe haven for immigrants either for stay or transit to a third country.

There was an incident of the discovery of mass graves in Wang Kelian, Perlis, near the MalaysianThailand border in Malaysia. It happened in May 2015 and was an incident which shocked the whole world. The Wang Kelian is an unassuming settlement but it has been thrust into the global spotlight after its discovery in the nearby jungle of human trafficking secret camps. This unorganized and very poor conditions of the secret camp were used by smugglers to keep illegal immigrants for ransom. Some of the campsites included wooden pens, and some with barbed wire guarded by sentry posts.

\footnotetext{
22 Tamara Makarenko (2004), "The Crime-Terror Continuum: Tracing the Interplay between Transnational Organised Crime and Terrorism," Global Crime, Vol. 6, No. 1, pp. 129-145.

${ }^{23}$ Makarenko (2004), “The Crime-Terror Continuum,” pp. 129-145.

${ }^{24}$ United Nations (n.d.), "Human Trafficking," United Nations Office on Drugs and Crime, retrieved 20 $2{ }^{\text {th }}$ September 2019, http://www.unodc.org/unodc/en/human-trafficking/what-is-human-trafficking.html.
} 
More than 100 graves were found in the surroundings of the camp. Some of those graves contained multiple bodies, raising the terrible prospect of hundreds of unexplained deaths. ${ }^{25}$

In terror-crime nexus context, the people involved in this crime used these people to gain money for two purposes; for their livings and also to support the movement. Thai separatists actively used this illicit activity to gain capital for their movement especially in the procurement of arms and weapons as well as pocket money. Smugglers have paid handsomely to officers and head of villagers in Thai sides of the border in order to ensure that their activities are carried out in a safe and sound manner. Later, transporters are involved in ferrying illegal immigrants to Malaysia or taking them into another boat to Australia or elsewhere. This activity is also connected with fake passports and forged documents as a preparation before deportation to third countries.

Terrorists make use of human trafficking as a way to gain money and subsequently become involved in other crimes as well. This will have bad impacts on the socio-economy of the country which has the potential to create social unrest in the long run. The government has to respond to this issue smartly by either using technology in curbing such incidents or accepting them legally and later on sending them back to their home countries or third countries, with the approval of UNHCR. But the main issue behind all of this is integrity. Personnel who deal with border issues have to be vigilant and alert; it doesn't matter who they are or what the conditions are. The main question remains whether Malaysia and neighboring countries are willing to seriously confront the border security issues. Until that time, Malaysia will be a fertile spot for terrorists in cultivating their ideologies, conducting their training and ultimately, launching their attacks.

\section{Kidnapping for Ransom}

Kidnapping for ransom, or in short KFR, was a major source of income for terrorists. KFR mainly happens in Sulu Seas which is located in Southern Philippines and north east coast of Borneo Malaysia or Sabah state. More or less, it is related with Malaysia as it happened many times in Malaysia offshore and has been rife since the end of World War II. After the 1972 independent movement emerged in Mindanao and the establishment of Mindanao National Liberation Front (MNLF), the KFR activities in Sulu Seas exacerbated.

The series of kidnapping will come together with videos of victims, in which the culprits will ask for some amount of money. KFR was recently associated with Abu Sayyaf Group (ASG), which is a group established in 1991. Before that, small groups operated on their own capacities and were involved in this crime. There are still many small groups which operate under the protection of ASG such as Rajah Solaiman and many more. All of these small groups will carry out the kidnappings and hand over to ASG to handle the deals. Europeans, Chinese, Japanese, Koreans, Malaysians and Indonesians are always in target especially non-Muslims.

The demand for money could reach USD10 million depending on the 'value' of the kidnapped individual. A demand of USD2 million was made for Warren Wodwell in 2011, USD5.6 million for two Germans, Dr Stefan Okenek and Henrike Dielen, USD16 million for Canadians, Robert Hall and John Riesdell, USD3 million ${ }^{26}$ for Wong's family of Malaysia and many more. Those who are not able to pay, are usually killed by beheading or shoot-out.

The connection between of KFR and Malaysians is more on the logistic part as Malaysia has better facilities and wealth. Many people who are involved in KFR also have dual citizenships and can easily move around between Southern Philippines and Sabah. These people will produce significant information for each of the incidents. There are many cases of such tourists and businessmen from Korea, China and Japan who have been kidnapped in resorts located in Malaysia. Police believe inside information gathered by ASG and their allies may have led to what had happened during the 2014 Singamata Resort's kidnapping.

\footnotetext{
${ }^{25}$ Beh Lih Yi (2015), "Malaysia Mass Graves: Villagers Tell of Migrants Emerging From Secret Jungle Camps,” The Guardian, retrieved $12^{\text {th }}$ February 2019, https://www.theguardian.com/world/2015/may/26/malaysia-mass-graves-villagers-tell-of-desperate-migrants-emergingfrom-jungle-camps.

${ }^{26}$ Erik French (2016), "Kidnapping Risk on the Rise in the Philippines," Global Risk Insights, retrieved 11 ${ }^{\text {th }}$ February 2019, https://globalriskinsights.com/2016/04/kidnapping-risk-philippines/.
} 
KFR is used as one of the easiest ways to fund terrorism operations. The Ransom amount for each of the cases could end up in millions. It has become a lucrative and easy way of getting funds. To a certain extent, the agenda of establishing their own government or kingdom is no longer an issue but it is more about money matters. KFR has been used only to find the best way to support their daily living. However, monies collected from this crime are also being used for the procurement of powerful weapons and other essential equipment, which enhanced its operational capabilities. It is also important to note that this group had intensified kidnapping activities by operating beyond its traditional areas of operation and staged daring and successful cross-border kidnappings. Ransoming hostages is significantly important for the ASG as a source of financing.

\section{Narcotics}

In Malaysia, smuggling, trafficking, and abuse of drugs has become a major issue and threat to national security. The success of drug syndicates drew questions on border integrity especially in Sungai Golok, Bukit Kayu Hitam and Padang Besar in northern Malaysia, as well as along borderlines in Sabah and Sarawak. Smuggling occurs every day at the country's borders and has increased significantly from day to day. Surrounding factors such as illegal entry, poverty, underground ring and human trafficking are also counted into this problem. ${ }^{27}$ Furthermore, Malaysia's strategic geographical position surrounded by the South China Sea and the Straits of Malacca, as well as porous borders between Thailand, Indonesia, Philippines and Singapore, is considered a gateway for illegal activities including drug-related crime. ${ }^{28}$

The trend of drug trafficking, particularly in Malaysia and Southeast Asia has changed drastically, shifting from the traditional type of drugs such as marijuana, opium and cannabis to hybrid synthetic drugs such as ice, ecstasy, methamphetamine and many more. Malaysia is located very close to the hotbed of drug ring in the golden triangle where Thailand, Myanmar and Laos are located. Malaysia has become a major transit place for hybrid drugs to be exported elsewhere mainly to European countries. Terrorists operate on the basis that the selling of drugs is allowed especially to the enemy, in order to pin them down. It can be seen in Afghanistan how it became the biggest opium producer in the world just a year after the takeover by the Taliban. The drug industry is recognized as one of the most demanding industry in which is being manipulated by terrorists. The same goes to Kosovo Liberation Army (KLA) Kosovo, Basque Homeland Liberty (ETA) Spain, Islamic Movement of Uzbekistan (IMU) Uzbekistan, LTTE Sri Lanka and FARC in Colombia; all of these groups used drugs as their main source of income as well as the catalyst to continue terror attacks.

Terrorists also have different colours of backgrounds and will find the best way to go to paradise, which is through jihad. Criminal-cum-jihadists had backgrounds that included street gangs, womanizing, drinking, sexual harassment, drug abuse and many more. The leader of IS, Abu Musab a-Zarqawi was taunted in prison for sexual assault and for being involved in street gangs. Salah Abdesalam, Brussels was attacked for his bad habit of drinking, smoking, clubbing, drugging and gambling. Once he decided to become a good Muslim, he chose salafi-jihadi extreme approach and landed as a terrorist. From all of this, we can see the connection between these people with drugs and the crime industry. They are not only experienced, but they also have networking that forms the link between terror and crime.

In Malaysia, there does not seem to be a clear evidence of drug-terrorism related activities, however, RMP believe the connection was established long time ago. The movement of foreign fighter jihadists in Malaysia also involved crime activities including drugs. A total of five hundred Malaysians and dozens of foreigners have been arrested in the past few years, and the government has been working with neighboring states and other partners to boost wider cooperation as well. Mass raids and arrests are not uncommon in Malaysia, with respect to a wide range of security concerns including piracy, drugs, terrorism, and illegal immigration.

\footnotetext{
${ }^{27}$ Mohd Mizan Aslam (2009), A critical study of Kumpulan Militan Malaysia, its wider connections in the region and the implications of radical Islam for the stabilitiy of South East Asia, Doctoral Thesis, Victoria University of Wellington, New Zealand, p. 210.

${ }^{28}$ Mohd Mizan Aslam (2009), A critical study of Kumpulan Militan Malaysia, p. 210.
} 
The threat from terror-crime nexus in the drug industry are nefarious and despicable. This alliance does not need a big scale; small and close cells are given greater autonomy to financing terrorism activities. It also creates new members who are willing to carry out violent attacks, if threatened. Hence, this industry will not stand alone; normally it will be associated with any illicit but lucrative activity including human trafficking, gambling, prostitution, kidnapping, money laundering and many more. It will create more problems to every nation and will multiply the cost of countering such activities.

\section{Money Laundering}

In terms of the dynamics of the international economic environment, economic related organized crimes including money laundering, has become a threat to Malaysia and the whole world security. Money laundering threatens all significant values of the society. It is also related to other crimes as well such as drug smuggling, human trafficking, arms smuggling, gambling, prostitution and many more. ${ }^{29}$

The concept of money laundering is extensive and started since the $20^{\text {th }}$ century in America. It can be defined as a process in which the income, which is reasonably suspected to have been acquired through criminal activities, has been transferred, exchanged or blended with legal funds in order to conceal its true nature, origin, use, movement or ownership. ${ }^{30}$ The easiest way to understand it is: money laundering is a process of making the obtained illegal funds appear legal. It can be done in various ways including using fake accounts, front companies and legitimate businesses.

According to the National Strategy for combating money laundering and terrorist financing, three phases are involved. The first phase is investment, followed by the concealment phase, and lastly is the integration phase. Dirty money from illicit activities is placed into a legal economic and financial activity in such a way that is impossible to disclose. Money laundering also involves a wide range of different transactions to hide the origin of the money and make it a legal means of the transaction on the money market.

Malaysia has a long journey in placing such a law to counter money laundering in the country. At the beginning, the authorities fought financial crimes under the Penal Code, the Companies Act 1965, and the Dangerous Drugs (Forfeiture of Property) Act 1988 and the Anti-Corruption Act 1997. However, The Anti-Money Laundering Act 2001 (AMLA) came into force on Jan 15, 2002. In March 2007, it was amended to include provisions to combat terrorism financing after the $9 / 11$ tragedy in the United States, and the original title was expanded to become Anti-Money Laundering and Anti-Terrorism Financing Act (AMLATFA).

So far, no cases in relation to terrorist activities in Malaysia were charged under the AMLATFA. It is because all of the cases were tried under SOSMA, POTA and POCA. One of the reasons for the arrest of the 9 terrorists including 6 French citizens and 1 US citizen in Sg Jerneh, Perlis on November 2018 was related to suspicious business activity. In the case of Li Safuan, a converted Muslim who used his travel company to channel money to a group of terrorists in Malaysia, he was charged under SOSMA and imprisoned for 7 years. A few more people were also arrested due to their involvement in giving amounts of money to terrorist related activities including the brother of Abu Wandy who transferred $\mathrm{RM} 3,000$ to him for terrorism funding.

\section{Robbery}

Indonesia has more numbers of bank robbery compared to Malaysia especially during the peak of JI operation in the region. JI collected millions of rupiah as part of their funding for terrorism-related activities. In a wider connection, robbery also happened in Mindanao, particularly in Marawi siege, from May to September 2017. Banks and shops including gold merchants looted by Maute group as the easiest way to gain funding. Iraq's invasion and securing billions of money and gold bullions became an inspirational incident for them. The Lahad Datu invasion by Kiram's movement in 2013

\footnotetext{
${ }^{29}$ Mohd Mizan, Iffah and Nur Aqilah, "De-radicalization programs in South-East Asia," p. 157.

${ }^{30}$ Borko Milosevic (2016), Money Laundering as a Form of Economic Crime in the Role of Financing Terrorism, Serbia, Facta Universitatis.
} 
tried to implement the method which ransacked the small city of Tanduo including banks and shops. Unfortunately, RMP and Malaysian Armed Forces (MAF) successfully encountered this attack before escalating to another city.

With help from JI Indonesia operative, Malaysia was marked by one robbery back in 2001. The Southern Bank, located in Petaling Jaya Selangor was robbed by KMM as part of the acquisition of non-believer's wealth or known as $f^{\prime}$ ' $i$. However, this robbery was botched by the unexpected presence of a second security guard inside the bank. Two KMM members were killed, one survived and went back to his hometown in Temerloh, Pahang. He was tracked because of the abandoned motorcycle outside of the bank which led to the arrest of nine others. Later, the names of JI top leader, Hambali, Nasir Abbas and ABB were also interrogated

KMM and JI worked together in securing funds through robbery. The fast act of RMP to halt their activities at an early stage has made significant impact. JI and KMM have very limited access to these activities in Malaysia. However, these groups see opportunities in Indonesia and Mindanao. Porous borders, lack of enforcement and dual citizenships are among factors contributing to the movement of these militants. With the help of locals and great pious appearances allows them to move around easily and make plans.

Since the year 2000, there have been dozens of bank heists conducted by numerous terrorist cells; some linked to Jemaah Islamiyyah, Mujahidin Indonesia Timur (Mujahidin of Eastern Indonesia or MIT), Abu Sayyaf Group (ASG) and many more. Besides banks, the terrorists have also robbed gold shops, mobile phone shops, post offices, money changers, internet cafes, grocery stores, and construction material shops. A total of Rp 1.8 billion (US\$180,000) from a series of bank heists was collected by MIT. While in the past, Jemaah Islamiyah (JI) and its splinter cells had conducted robberies to supplement their funding for terrorist attacks, in August 2002 three men robbed 5.5 pounds of gold and $\$ 500$ in cash from a jewelry store on Java Island, with an estimated worth of US $\$ 90,000$. It was ultimately used to finance the terrorism related attacks. The majority of the funding was used for living expenses and logistical details, since the actual cost of the bomb materials and vehicles was probably less than US\$10,000.

The Philippines is known as a country with the biggest amount of organized crime in the world, including robberies. ${ }^{31}$ The number of unlicensed arms and weapons are so big and each can be bought for as little as USD100. Hence, living below poverty lines also contributed to the problem. This made terror and crime work hand in hand in crime activities especially in the southern part of Philippines as seen in many reports. Some Malaysians who fled for Phillipines: Zulkifli Khir, Najib Hussein, and Umar Patek also became involved in robbery and looting activities such as the 2002 Zamboanga bank robbery and in 2017, the Marawi siege.

\section{Conclusion}

In conclusion, the real threat of terror-nexus exists in Malaysia and have wider networking in the region and other parts of the world. There are many significant reasons why terror-nexus becomes a primary challenge for Malaysia. Located in Southeast Asia, this region particularly, has lots of natural resources, porous borders, complexity of society, lack of integrity and many more factors which helped these activities to flourish. All of this can be manipulated at any time.

Supply and demand are always in place especially when this kind of activity is linked to underground business and connected to some influential politicians in the country. The creation of a borderless country by the impact of globalization played a major role in shaping terror-crime nexus. ASEAN countries are no longer far from each other even with 651million population from 10 countries spread out in 4.5million kilometers. Each of the conflict areas in this region have their uniqueness in terms of blood connection or kinship. The Mindanao conflict escalates the problems between Southern Philippines and Sabah Malaysia. The Pattani conflict is associated with people from Southern Thailand and Kelantan Malaysia. The Rakhine conflict also involved people in Thailand, Bangladesh and Myanmar. All these people are connected because of kinship and will have a sense of belonging

${ }^{31}$ Jeffrey Hays (2008), "Crime in the Philippines," Facts and Details, retrieved $11^{\text {th }}$ February 2019, http://factsanddetails.com/southeastasia/Philippines/sub5_6f/entry-3908.html. 
and strong brotherhood connection. Thus, it will help and, in some way, will be protecting their interest in crime-terror nexus such as kidnapping for ransom, assassination, robbery, drug and human trafficking and many more.

The main issue behind this is lack of integrity, a factor in creating terror-crime nexus either in Malaysia or elsewhere. Without integrity, the movement and operation of crime-terror came as easy as pie. Corruption is reported in these conflict areas involving military, government officers, local authorities and individuals. In one hand, it looks like they want to solve this problem, but on the other hand they will let this problem exist because it will be a source of income for some of them. Some reports also suggest that military personnel were also involved in escalating the problems because of the budget which comes from the federal from time to time.

In the terror-crime nexus among militant groups in Malaysia, all of them share the same ideology which is the struggle to establish an Islamic state by violence means. The main objective is trying to create chaos and panic in the society and later will maneuver to country's social and political instability. All of these groups declined the constitutional law and the system of democracy which is implemented by the Malaysian government. These groups choose to act violently as a way to show their existence in the country. Later, these groups tie up with criminal rings to gain sufficient funding for terror activities.

Extremists is always ready to manipulate social grievances for their own political agenda. It has to be adequately addressed to prevent exploitation by extremists. Malaysia should be well aware that the current threat from radicals is important; a type of political warfare that requires not only security action but also a comprehensive counter-strategy. Malaysia should not feel complacent about what they have done so far because extremists will always seek any opportunity to strike. ${ }^{32}$ The threat from radicals will continue unless comprehensive action can be taken. Initiatives taken by the Malaysian government may take a long time to succeed, but it is absolutely essential and has to be by any means.

Exploitations of local dynamics, such as poverty, corruption, and lack of enforcement contributed to the terror-crime nexus. These issues should be addressed wisely not only by the Malaysian government, because it has to be a priority for most of the governments in this region. The work between counter terrorism and counter organized crime is needed because of the strategic ally between terrorism and crime, as discussed above. The future problem in Malaysia and this region is more on countering terror financing in a wider spectrum across borders, religions and ethnicities.

\section{References}

Abas, N. (2007), Interview, $17^{\text {th }}$ of December 2007 at Jakarta Selatan, Indonesia.

Arianti, V. and Yaoren, Kenneth Yeo (2017), "How Terrorists Use Crypto Currency in Southeast Asia," The Diplomat, retrieved $1^{\text {st }}$ July 2020, https://thediplomat.com/2020/06/how-terrorists-usecryptocurrency-in-southeast-asia/.

Duhaime, C. (2015), “Terrorist financing and the Islamic State," Duhaime Advisory, retrieved $17^{\text {th }}$ November 2015, http:/www.duhaimelaw.com/wp-content/uploads/2015/04/White-Paper-TerroristFinancing-Methods1.pdf.

French, Erik (2016), "Kidnapping Risk on the Rise in the Philippines," Global Risk Insights, retrieved $11^{\text {th }}$ February 2019, https://globalriskinsights.com/2016/04/kidnapping-risk-philippines/.

Gunaratna, Rohan (2018), "Counterterrorism: ASEAN Militaries' Growing Role - Analysis," RSIS Commentaries, retrieved $8^{\text {th }} \quad$ June 2018, https://www.rsis.edu.sg/wpcontent/uploads/2018/03/CO18042.pdf.

Gunaratna, Rohan and Mohamed Ali (2014), Terrorist Rehabilitation: A New Frontier In Counterterrorism, London: Imperial College Press.

${ }^{32} \mathrm{~N}$. Abas (2007), Interview, $17^{\text {th }}$ December at Jakarta Selatan, Indonesia. 
Hariyadi, Mathias (2012), "Islamist Terrorist Suspected in Yogyakarta Robbery," Asianews, retrieved $1^{\text {st }}$ March 2019, http://www.asianews.it/news-en/Islamic-terrorists-suspected-in-Yogyakarta-bankrobbery-25303.html.

Hawramy, F., Mohammed, S. and Harding, L. (2014), "Inside Islamic State's oil empire: how captured oilfields fuel Isis insurgency," The Guardian, retrieved $19^{\text {th }}$ November 2019 , http://www.theguardian.com/world/2014/nov/19/-spislamic-state-oil-empire-iraq-isis.

Hays, Jeffrey (2008), "Crime in the Philippines," Facts and Details, retrieved $11^{\text {th }}$ February 2019, http://factsanddetails.com/southeast-asia/Philippines/sub5_6f/entry-3908.html.

Kamarulnizam Abdullah (1999), "National Security and Malay Unity: The Issue of Radical Religious Elements in Malaysia," Contemporary Southeast Asia, Vol. 21, No. 2, 261-282.

Laub, Z. and Masters, J. (2014), "ISIL in Iraq and Syria," Council on Foreign Relations, retrieved $22^{\text {nd }}$ September 2014, http://www.cfr.org/iraq/islamic-state-iraq-syria/p14811.

Levitt, M. (2014), "Terrorist financing and Islamic State - Testimony submitted to the House of Committee on Financial Services," Washington Institute, retrieved $16^{\text {th }}$ November 2015, $\mathrm{http} / / / \mathrm{www}$.washingtoninstitute.org/policyanalysis/view/terrorist-financing-and-the-islamic-state.

Makarenko, Tamara (2004), "The Crime-Terror Continuum: Tracing the Interplay between Transnational Organised Crime and Terrorism," Global Crime, Vol. 6, No. 1, pp. 129-145.

Malaysia Government White Paper (1986), The Memali Incident, Kuala Lumpur: Government of Malaysia.

Malaysia Government White Paper (1988), Towards Preserving National Security, Kuala Lumpur: Malaysia Government.

Milosevic, Borko (2016), Money Laundering as a Form of Economic Crime in the Role of Financing Terrorism, Serbia, Facta Universitatis.

Mohd Mizan Aslam (2005), "Asian and globalization: An analysis from Tun Mahathir's perspectives," Paper presented at the International Conference of Asian Scholars, Shanghai.

Mohd Mizan Aslam (2008), "Operational and ideological challenges in Islamic militancy in Malaysia: The case of Kumpulan Militan Malaysia (KMM)," n Md Yatim Othman (ed.), Malaysia in Various Issues: A Collection of Essays, New Zealand: Victoria University of Wellington, 148-162.

Mohd Mizan Aslam (2009), A critical study of Kumpulan Militan Malaysia, its wider connections in the region and the implications of radical Islam for the stability of South East Asia, Doctoral Thesis, Victoria University of Wellington, New Zealand.

Mohd Mizan Aslam (2012), The Typology of Radicalism in Southeast Asia, Kangar: Penerbit UniMAP.

Mohd Mizan Aslam (2016), "Drugs and Cross Border Terrorism," Keynote paper presented at the $1^{\text {st }}$ International Joint Conference on Drugs, Social Sciences and Technology (DRUGSTECH), Universitas Ubudiah Indonesia, Banda Acheh, Indonesia, 30-31 ${ }^{\text {st }}$ October 2016.

Mohd Mizan Aslam (2019), Cross Border Terrorism in Terrorist Rehabilitation and Community Engagement di Malaysia and Southeast Asia, London: Routledge.

Mohd Mizan Aslam (2020), "Pemahaman Agama Ketika Wabak," Malaysiakini, retrieved $11^{\text {th }}$ April 2020, https://www.malaysiakini.com/columns/520063. 
Mohd Mizan Aslam, Iffah Bazilah Othman and Nur Aqilah Khadijah Rosli (2016), "De-radicalization programs in South-East Asia: A comparative study of rehabilitation programs in Malaysia, Thailand, Indonesia and Singapore," Journal of Education and Social Sciences, Vol. 4, 154-160.

Osborne, S. (2015), "ISIS earns $\$ 50$ million month from oil sales," Independent, retrieved $24^{\text {th }}$ October 2020, www.independent.co.uk/news/world/middle-east/isis-earns-50m-a-month-from-oil-salesa6707146.html.

R. Hashim (2007), Interview, 30 ${ }^{\text {th }}$ December 2007 at Bukit Aman Police Head Quarters, Kuala Lumpur, Malaysia.

Ryder, Nicholas (2013), "Out with the old and...in with the old? A critical review of the financial war on terrorism on the Islamic state of Iraq and Levant," Studies in Conflict \& Terrorism, Vol. 41, No. 2, $79-95$.

United Nations (n.d.), "Human Trafficking," United Nations Office on Drugs and Crime, retrieved $20^{\text {th }} \quad$ September 2019, http://www.unodc.org/unodc/en/human-trafficking/what-is-humantrafficking.html.

Vision of Humanity (2017), Global Terrorism Index, retrieved $12^{\text {th }}$ February 2019, http://visionofhumanity.org/app/uploads/2017/11/Global-Terrorism-Index-2017.pdf.

Yi, Beh Lih (2015), "Malaysia Mass Graves: Villagers Tell of Migrants Emerging From Secret Jungle Camps," The Guardian, retrieved $12^{\text {th }}$ February 2019, https://www.theguardian.com/world/2015/may/26/malaysia-mass-graves-villagers-tell-of-desperatemigrants-emerging-from-jungle-camps. 
Journal of Al-Tamaddun, Vol. 15 (2), 2020, 15-27 